\title{
THE CORRELATION BETWEEN THE FDI AND THE GDP IN THE EU15 MEMBER STATES IN THE PERIOD 1980-2014
}

\author{
Petar Kurečić, Goran Kozina
}

Preliminary communication

The paper studies the correlation between the FDI and the GDP in the EU15 member states, between 1980 and 2014 . The FDI was set as an independent variable, and the GDP as a dependent variable. The aim of the paper is to study the correlation between the FDI and the GDP in the states that founded the EU (then the EEC) or joined the EEC/EU up to 1996. The following research hypotheses were set: no. 1, stating that the FDI and the GDP in the EU15 member states show a significant correlation, and research hypothesis no. 2, claiming that EU15 member states of "the EU15 economic periphery" show a higher correlation than the EU15 member states of "the EU15 economic core". The NULL hypothesis, which claims that the FDI and the GDP in EU15 member states do not show a significant correlation, was also set. The Pearson correlation coefficient values verified the research hypotheses for most of the studied states.

Keywords: EFTA; FDI; GDP; Pearson correlation coefficient; the EU15 member states

Korelacija između izravnih inozemnih ulaganja i bruto domaćeg proizvoda u državama EU15 u razdoblju 1980. - 2014.

Prethodno priopćenje Članak se bavi istraživanjem korelacije između izravnih inozemnih ulaganja (FDI) i BDP-a u prvih 15 članica Europske unije (EU15), u razdoblju 1980. 2014. FDI su postavljena kao nezavisna, a BDP kao zavisna varijabla. Namjera članka je istraživanje korelacije FDI-a i BDP-a među državama koje su osnovale EU (tada EEZ) ili se priključile EEZ ili EU do 1996. Postavljene su sljedeće hipoteze istraživanja: hipoteza br. 1, kojom se tvrdi da FDI i BDP u državama EU15 pokazuju značajnu korelaciju, te hipoteza br. 2, kojom se tvrdi da države EU15 koje pripadaju "ekonomskoj periferiji EU15" pokazuju značajniju korelaciju od država EU15 iz "ekonomske jezgre EU15". Također je postavljena i nulta hipoteza, kojom se tvrdi da u navedenim državama nema značajne korelacije FDI-a i BDP-a. Vrijednosti Pearsonova koeficijenta korelacije verificirale su postavljene hipoteze istraživanja za većinu istraživanih država.

Ključne riječi: bruto-domaći proizvod (BDP); države članice EU15; Europsko udruženje slobodne trgovine (EFTA); izravna inozemna ulaganja (FDI); Pearsonov koeficijent korelacije.

\section{Introduction}

The paper studies the correlation between foreign direct investment, net inflows (FDI) and gross-domestic product (GDP) in the 15 member states of the European Union (the EU15) between 1980 and 2014. The aim of the paper is to study the correlation between the FDI and the GDP in the "old" EU member states i.e. the states that founded the EU (then the EEC) or joined the EEC or the EU up to 1996. The states that joined the EU after 1995 were not an object of this study, since their historical path towards joining the EU is quite different. Mainly, we refer to the fact that in most cases (except two: Cyprus and Malta) these are post-communist states. All these states, including the two non-post-communist, joined the EU decades after most of the West European or South European EU member states, and they did not belong to the second European common market (besides the EU), the European Free Trade Association (EFTA) before joining the EU.

According to UNCTAD (2005), global FDI inflows increased from approximately U\$55 billion in 1980 to around U\$1400 billion in 2000. This unprecedented growth in FDI inflows has prompted academic economists and policy makers alike to devote much more effort to understanding the empirical relationships between GDP growth and FDI inflows in host countries [1].

In the literature devoted to the influence of the FDI on economies, the research on the determinants of the geographical pattern of FDI distribution usually focuses on the factors that determine why some states manage to draw the FDI in higher levels than others [2]. Concurrently, most of the studies of interdependence between the FDI and economic growth are devoted either to the developing or the transition economies.

Most studies generally indicate that the effect of the FDI on growth depends on other factors such as the degree of complementarity and substitution between domestic investment and the FDI, and other state-specific characteristics. The extent to which the FDI contributes to growth depends on the economic and social conditions in the recipient state. States with a high rate of savings, an open trade regime and high technological levels would benefit from increased FDI to their economies. However, the FDI may have a negative effect on the growth prospects of the recipient economy if they result in substantial reverse flows in the form of remittances of profits, and dividends and/or if the multinational corporations (MNCs) obtain substantial or other concessions from the host state [3].

Foreign direct investment (FDI) is a particularly important element of economic integration, because it opens possibilities for accelerated growth, technical innovation and enterprise restructuring, as well as capital account relief $[4,5]$. EU membership can be viewed as a determining element of the operating business environment, and this may directly influence the rate of FDI flows.

Using a statistical analysis of possible causal relationships between exports, inward foreign investment and economic growth in the case of Portugal, showed that exports and the FDI foster growth in the long-run while in the short-run there is a bi-directional causal relationship 
between the FDI and growth and a univariate causal relationship running from the FDI to exports. The FDI is viewed as a major determinant of economic growth, both directly and indirectly, via exports for both long and short-run cases [6].

Panel fixed-effects estimation can be used to identify the relationship. The research of 32 developed and developing nations showed that the FDI can lead to better technology and improved management in the host country. However, the evidence was rather weak on whether the FDI actually creates economic growth [7].

Time-series were used for data in 11 developing countries, and evidence was found of growth enhancement from the FDI. However, the magnitude again appeared to depend on host country conditions [8]. With the aid of panel data for 80 developed and developing countries, Choe conducted a Granger causality test for the GDP and the FDI. He found that FDI Grangercaused economic growth and vice versa, but the effects are more apparent from growth to FDI [9].

The level of the FDI in some state unequivocally depends on numerous contributing factors [10], therefore it is not the intention of this paper to determine the factors of FDI net inflows in the EU15 member states, but merely to study the correlation between the FDI and the GDP in the member states of the same integration, in this case the EU in the studied period and to test the research hypotheses that were stated.

\section{Methodology}

After extracting the data from the web pages of the World Bank [11], foreign direct investment, net inflows (FDI) and gross-domestic product (GDP) were used in calculating the Pearson correlation coefficient $(\mathrm{R})$, as independent and dependent variables. Depending on the different regional positions, for the purpose of this paper, the states of the EU15 were divided into two groups:

1) "The EU15 economic core" - Austria, Belgium, Denmark, Finland, France, Germany, Luxembourg, the Netherlands, Sweden, and the United Kingdom.

2) "The EU15 economic periphery" - Ireland, Greece, Italy, Portugal, and Spain.

The group of the "EU15 economic periphery" mentioned here is the same group of states that in 2010 became to be known as PIGS (Portugal, Ireland, Greece, and Spain), or together with Italy, as PIIGS (the PIGS states plus Italy) characterized primarily by economic recession that lasted longer than in most of the states of Western and Northern Europe, and especially high public debt [12].

\subsection{Research hypotheses}

The research hypothesis and NULL hypothesis were set:

Research hypothesis no. 1 - The FDI and the GDP in the EU15 member states show a significant correlation in which the FDI represents an independent variable and the GDP a dependent variable.
Research hypothesis no. 2 - The FDI and the GDP in the EU15 member states of "the EU15 economic periphery" show a higher correlation than the FDI and the GDP in the states of "the EU15 economic core".

The NULL hypothesis - The FDI and the GDP in the EU15 member states do not show a significant correlation.

\subsection{Methodological constraints}

The time sequence of 35 consecutive years (for all studied states where data were available) was taken in order to get a relevant value of correlation. We did not want to use the data from various sources, and the first year for which data were available for most of the studied states was 1980 .

For the EU15 member states where data were not available for most of the studied years (for Belgium the data were available for only 13 years, 2002-2014, and for Luxembourg the data were available for only 12 years, 2002-2013) the calculation was also done, however, these results should be considered with extreme caution and cannot be compared with results where 35 or in some cases 34 pairs were calculated. As mentioned before, we were faced with methodological constraints regarding the unavailability of data for all years in more than a half of the EU15 member states studied. Among the EU15 member states, the data were available for all targeted years in the following cases: Austria, Denmark, France, Germany, Italy, the Netherlands, Spain, and the United Kingdom. The data for 34 years were available for Finland, Greece, Ireland, Portugal, and Sweden. These data were available for the period 1980-2013, except for Greece, where data were available for two split periods (1980-1997, 1999-2014), therefore leaving the data for 1998 blank. However, in the case of Greece, we decided to calculate the Pearson correlation coefficient $(\mathrm{R})$ for the 34 years that were available, knowingly omitting the year 1998 from the calculation.

The present EFTA member states except Lichtenstein (due to the unavailability of data for the FDI) were also studied, as control group, due to their economies' connectedness with the economies of the EU15 member states. Among the present EFTA members, complete data were available only for Iceland. Data for 34 years were available for Norway (1980-2013), and for 31 years in the case of Switzerland (1983-2014).

Despite these constraints, we decided to calculate the Pearson correlation coefficient (R) for all EU15 member states and present EFTA members (except Lichtenstein) to see how the FDI and the GDP correlated in the previous decades, and especially to try to find the probable reasons for this correlation. After calculating the $R$-values, the $P$-value was set at 0.05 and 0.01 in order to test the relevance of data at both $P$-values.

\section{Results and discussion}

The results show a significant correlation, according to the value of the Pearson correlation coefficient $(R)$ between the FDI and the GDP, therefore confirming research hypothesis no. 1 for most of the studied states. 
Table 1 Pearson correlation coefficient $(R)$, number of years $(N), P$-value, and the confirmation of the NULL-hypothesis at different $P$-values $(0.05$ and

\begin{tabular}{|c|c|c|c|c|c|}
\hline State & $\begin{array}{l}\text { Pearson correlation } \\
\text { coefficient }(R \text {-Score })\end{array}$ & Number of years $(N)$ & $P$-value & $\begin{array}{c}\text { Confirmation of the } \\
\text { NULL-hypothesis at } \\
P \text {-value } 0.05\end{array}$ & $\begin{array}{c}\text { Confirmation of the } \\
\text { NULL-hypothesis at } \\
P \text {-value } 0.01\end{array}$ \\
\hline Austria & 0.362 & 35 & 0.033 & Rejected & Confirmed \\
\hline Belgium & 0.174 & 13 & 0.570 & Confirmed & Confirmed \\
\hline Denmark & 0.065 & 35 & 0.711 & Confirmed & Confirmed \\
\hline Finland & 0.317 & 34 & 0.068 & Confirmed & Confirmed \\
\hline France & 0.545 & 35 & 0.0007 & Rejected & Rejected \\
\hline Germany & 0.428 & 35 & 0.0104 & Rejected & Confirmed \\
\hline Luxembourg & 0.235 & 12 & 0.462 & Confirmed & Confirmed \\
\hline Netherlands & 0.626 & 35 & 0.00006 & Rejected & Rejected \\
\hline Sweden & 0.339 & 34 & 0.0498 & Rejected & Confirmed \\
\hline United Kingdom & 0.628 & 35 & 0.00005 & Rejected & Rejected \\
\hline Median value & 0.487 & & & & \\
\hline
\end{tabular}

\begin{tabular}{|c|c|c|c|c|c|}
\hline Greece & 0.669 & 34 & 0.00001 & Rejected & Rejected \\
\hline Ireland & 0.814 & 34 & 0.00001 & Rejected & Rejected \\
\hline Italy & 0.565 & 35 & 0.0004 & Rejected \\
\hline Portugal & 0.786 & 34 & 0.00001 & Rejected & Rejected \\
\hline Spain & 0.806 & 35 & 0.00001 & Rejected & Rejected \\
\hline Median value & 0.786 & \multicolumn{4}{l}{}
\end{tabular}

Table 2 Pearson correlation coefficient $(R)$, number of years $(N), P$-value, and the confirmation of the NULL-hypothesis at different $P$-values $(0.05$ and

\begin{tabular}{|c|c|c|c|c|c|}
\hline State & $\begin{array}{c}\text { Pearson correlation } \\
\text { coefficient } \\
(R \text {-Score })\end{array}$ & $\begin{array}{c}\text { Number of } \\
\text { years }(N)\end{array}$ & $P$-value & $\begin{array}{c}\text { Confirmation of the } \\
\text { NULL-hypothesis at } \\
P \text {-value } 0.05\end{array}$ & $\begin{array}{c}\text { Confirmation of the } \\
\text { NULL-hypothesis at } P \text { - } \\
\text { value } 0.01\end{array}$ \\
\hline Iceland & 0.628 & 35 & 0.00005 & Rejected & Rejected \\
\hline Norway & 0.770 & 34 & 0.00001 & Rejected & Rejected \\
\hline Switzerland & 0.357 & 31 & 0.049 & Confirmed \\
\hline Median value & 0.628 & &
\end{tabular}

When the $P$-value was set at $0.05, R$-values of four studied EU15 member states (Belgium, Denmark, Finland, and Luxembourg) confirm the NULLhypothesis, therefore showing no significant correlation between the FDI and the GDP in the studied period. However, we again have to emphasize that results for Belgium and Luxembourg were based on the number of years studied, which is not sufficient to accept the relevance of this data, especially compared to the data for the other studied states. The $R$-values for Denmark (35 years studied) and Finland (34 years studied) confirm the NULL hypothesis even at $P$-value 0.05 .

When the $P$-value was set at $0.01, R$-values for Austria and Germany (for both, 35 years were studied), as well as Sweden (34 years studied) also confirm the NULL hypothesis. Among the present EFTA member states studied, all reject the NULL hypothesis when the $P$-value was set at 0.05 , showing a significant correlation between the FDI and the GDP. Switzerland (31 years studied) confirms the NULL hypothesis only when the $P$-value was set at 0.01 .

The states that confirm the NULL hypothesis rejected research hypothesis no. 1 . The relevance of this rejection was, however, different for some states, depending on the set $P$-value.

If the states from the first group ("the EU15 economic core") that confirmed the NULL hypothesis are excluded, the median R-value for the states of "the EU15 economic core" is 0.487 . The median $R$-value for the five states of "the EU15 economic periphery" is 0.786 . The difference in the Pearson correlation coefficient value is significant, therefore confirming research hypothesis no. 2. At the same time, the median $R$-value for the three studied EFTA member states is 0.628 .

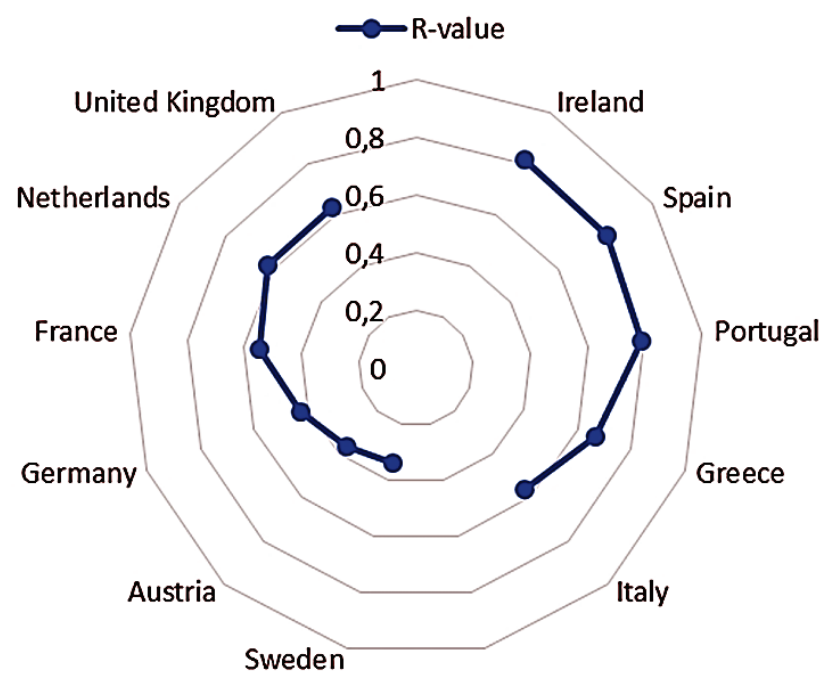

Figure 1 The calculated Pearson correlation coefficient $(R)$ between the FDI and the GDP of the EU15 member states that rejected the NULL hypothesis

\section{Conclusion}

Most of the EU15 member states show a significant correlation, measured by the Pearson correlation coefficient $(R)$ in the period of over three (34 or 35 years in most cases) decades that was studied for most of the mentioned states. The present EFTA member states also 
show a significant correlation of the FDI and the GDP in the studied period. Among the EU15 member states that show significant correlation at $P$-value 0.05 , there is a visible difference between the states of "the EU15 economic core" states and the "EU15 economic periphery" states. None of the states of "the EU15 economic periphery" confirmed the NULL hypothesis. The $R$-values of states that show the strongest correlation of all EU15 member states are the ones of Ireland, Spain, Portugal, and Greece. The $R$-value for Italy shows a somewhat weaker correlation (behind the United Kingdom and the Netherlands). The studied EFTA members show a median $R$-value that is positioned between the two studied groups of the EU15. When discussing regional differences and similarities, it must also be noted that among the Scandinavian states, the $R$ values of the EU members (Denmark, Finland, and Sweden) show a much weaker correlation between the FDI and the GDP than the $R$-values of the Scandinavian EFTA members (Iceland and Norway).

\section{$5 \quad$ References}

[1] Wijeweera, A.; Villano, R.; Dollery, B. Economic Growth and FDI Inflows: A Stochastic Frontier Analysis. // Journal of Developing Areas. 43, 2(2010), pp. 143-158. https://doi.org/10.1353/jda.0.0059

[2] Kurečić, P.; Luburić, G.; Šimović, V. The Interdependence of GDP per capita and Foreign Direct Investment in the Transitional Economies of Central and Eastern Europe. // Proceedings of the 9th Economic and Social Development Conference / Varaždin, 2015, pp. 192-199.

[3] Buckley, P. J.; Clegg, J.; Wang, C. The impact of inward FDI on the performance of Chinese manufacturing firms. // Journal of International Business Studies. 33, 4(2002), pp. 637-655. https://doi.org/10.1057/palgrave.jibs.8491037

[4] Garibaldi, P.; Mora, N.; Sahay, R.; Zettelmeyer, J. What Moves Capital to Transition Economies. // IMF Conference "A decade of transition" Proceedings / Washington, D.C., 1999.

[5] Holland, D.; Pain, N. The Diffusion of Innovations in Central and Eastern Europe: A Study of the Determinants and Impact of Foreign Direct Investment. London: National Institute of Social and Economic Research, 1998.

[6] Andraz, J. M.; Rodriguez, P. M. What causes economic growth in Portugal: exports or inward FDI? // Journal of Economic Studies. 37, 3(2010), pp. 267-287. https://doi.org/10.1108/01443581011061276

[7] De Mello, L. R. Foreign direct investment-led growth: evidence from time series and panel data. // Oxford Economic Papers. 51(1999), pp. 133-151. https://doi.org/10.1093/oep/51.1.133

[8] Choe, J. I. Do foreign direct investment and gross domestic investment promote economic growth? // Review of Development Economics. 7, 1(2003), pp. 44-57. https://doi.org/10.1111/1467-9361.00174

[9] Zhang, K. H. Does foreign direct investment promote economic growth? Evidence from East Asia and Latin America. // Contemporary Economic Policy. 19, 2(2001), pp. 175-185.

[10] Dunning, J. Institutional reform, FDI and European transition economies. Reading, U.K.: Henley Business School, University of Reading, 2004. https://doi.org/10.1111/j.1465-7287.2001.tb00059.x

[11] http://data.worldbank.org/indicator/BX.KLT.DINV.CD. WD/countries. (5.8.2015)
[12] http://data.worldbank.org/indicator/NY.GDP.MKTP.CD. (5.8.2015)

[13] http://stats.areppim.com/stats/stats_gvtdebtxgdp_02x11_pii gs.htm. (6.8.2015)

[14] http://news.bbc.co.uk/2/hi/8510603.stm. (6.8.2015)

\section{Authors' addresses}

Petar Kurečić, PhD, Assistant Professor

University North

Trg Žarka Dolinara 1, 48000 Koprivnica, Croatia

E-mail: petar.kurecic@unin.hr

Goran Kozina, PhD, Associate Professor

University North

Ulica 104. brigade 3, 42000 Varaždin, Croatia

E-mail: goran.kozina@unin.hr 